\title{
Pengembangan Keprofesian Berkelanjutan Guru untuk Meningkatkan Mutu Pendidikan
}

\author{
Nurkolis Siri Kastawi \\ Manajemen Pendidikan Universitas PGRI Semarang \\ nurkolis@gmail.com \\ Yovitha Yuliejantiningsih \\ Manajemen Pendidikan Universitas PGRI Semarang \\ juliejanti@gmail.com
}

\begin{abstract}
The purpose of this study to find out (1) the steps of continuous professional development (CPD) of teachers, (2) the methods and techniques of CPD, (3) the models of CPD, (4) thefinancing of $C P D$, and (5) the constraints of CPD. The research approach is qualitative while the type is phenomenological. The study was conducted in Demak Regency in 2019. Data collection techniques used questionnaires, interviews, and documentation. The research step follows the Miles and Huberman model. Analysis of data using qualitative research software NVivo 11 Plus. The results showed (1) the steps of CPD consist of need assessment, implementation, and evaluation, (2) the most widely used methods were education and training, lectures, simulations, discussions, and behavior modeling, (3) the models most widely used professional learning groups, (4) the biggest funding source from the personal of teachers and local government, and (5) the main constraints are in terms of time, funding, lack of programmability, and lack of assistance. The intensive CPD implementation has succeeded in improving the quality of education in Demak District. In order for CPD to improve more quality of education, it is suggested that several things (1) CPD steps need to be improved starting from the measurement of teacher needs to evaluation, (2) the methods, techniques, and models that are still rarely used should be tried to apply, (3) it needs to explore funding from the public, (4) minimize the main obstacles that arised, and (5) the need of operational policy from District Education Office of Demak.
\end{abstract}

Keywords: CPD Effectiveness, CPD Methods and Techniques, CPD Model, CPD Financing, $K K G \& M G M P$

\section{Article Info}

Received date: 16 November 2019 Revised date: 18 Desember $2019 \quad$ Accepted date: 20 Desember 2019

\section{PENDAHULUAN}

Kementerian Pendidikan Republik Indonesia telah melakukan pemetaan kompetensi guru sejak tahun 2012. Pada saat itu diketahui bahwa rata-rata kompetensi pedagogik dan profesional guru secara nasional adalah 43 pada skala 100 sebagaimana tertuang pada Lampiran Peraturan Presiden RI No. 2 tahun 2015 tentang RPJMN 2015-2019, Buku II. Sementara itu kompetensi pedagogik dan profesional guru di Jawa Tengah mencapai 50,44 pada skala 100 (Kemdikbud, 2015).

Dalam Peraturan Presiden RI No. 2 tahun 2015 tersebut, kompetensi guru ditargetkan terus meningkat dari tahun ke tahun. Target kompetensi guru pada tahun 2018 
adalah 75 dan target pada tahun 2019 menjadi 80. Dengan membandingkan antara kondisi nyata tahun 2015 dengan target tersebut, kompetensi pedagogik dan profesional guru masih jauh berbeda.

Guna meningkatkan kompetensi guru di Indonesia, maka arah kebijakan dan strategi pembangunan sub bidang pendidikan diprioritaskan salah satunya adalah pelaksanaan pengembangan profesional berkelanjutan (PPB) bagi guru dalam jabatan melalui latihan berkala dan merata. Juga dilakukan penguatan kelompok kerja guru (KKG) dan Musyawarah Guru Mata Pelajaran (MGMP). Selain itu juga diprogramkan pembinaan karir dan pengembangan profesi kepala sekolah serta pengawas sekolah. Pengembangan profesional berkelajutan (PPB) bagi guru lebih dikenal dengan sebutan pengembangan keprofesian berkelanjutan (PKB) bagi guru.

Dengan adanya Peraturan Presiden tersebut semestinya pemerintah pusat dan pemerintah daerah sudah melakuan berbagai upaya PBB atau PKB agar para guru semakin profesional. Namun beberapa pihak sangsi terhadap pelaksanaan PBB atau PKB mengingat anggaran pemerintah pusat dan pemerintah daerah yang sangat terbatas untuk memberikan pendidikan dan pelatihan kepada para guru.

Menurut Damin (2011: 8), di Indonesia hanya sebagian kecil $(5 \%)$ dari guru memiliki peluang mengembangkan keprofesiannya atas prakarsa lembaga baik itu pemerintah pusat maupun pemerintah daerah. Jika pelatihan diberikan secara merata, setiap guru di Indonesia hanya memiliki peluang mengikuti pengembangan profesi satu (1) kali dalam kurun waktu 20 tahun. Maka Danim menyarankan agar para guru melakukan pengembangan profesional secara mandiri.

Memperhatikan kemampuan keuangan pemerintah pusat dan keuangan pemerintah daerah yang tidak memungkinkan untuk 158 mengembangkan profesionalisme semua guru, maka perlu strategi khusus agar profesionalisme guru dapat terus dikembangkan.

Di Indonesia, pengembangan keprofesian guru telah secara serius dimulai pada tahun 2010 sehingga masih perlu dilakukan banyak kajian guna mendapatkan gambaran yang komprehensif. Namun penelitian tentang implementasi PKB di Indonesia secara komprehensif belum banyak ditemukan. Di antara penelitian PKB dilakukan oleh Sianturi (2013), Wuryandini (2014), dan Maksum (2015). Studi kasus yang dilakukan Sianturi (2013) menemukan kebutuhan pengembangan keprofesian guru berdasarkan karakteristik mereka. Penelitian Wuryandini (2014) menyatakan bahwa hanya sedikit guru yang melakukan pengembangkan keprofesian secara komprehensif. Studi kasus yang dilakukan Maksum (2015) menemukan bahwa PKB belum dilakukan secara menyeluruh dan kurang adanya motivasi internal dari guru sendiri.

Sedangkan di negara maju, PKB adalah suatu keniscayaan. Menurut Henderson (2007) masyarakat sudah berperan aktif dalam PKB seperti di Australia.Di Hongkong seperti dilaporkan Chow (2013) pengembangan profesionalisme guru mata pelajaran sudah marak dilakukan di sekolah dan kepala sekolah memiliki peran penting dalam PKB.Di Amerika Serikat (Gallo-Fox dan Scantlebury, 2016) PKB salah satunya dilakukan dengan kolaborasi antara guru dengan menjadi coteacher bagi guru lain.

PKB adalah bagian dalam proses manajemen sumber daya manusia. Menurut Everard, Morris, dan Wilson (2004: 74-98) manajemen sumber daya manusia mencakup recrutment, employment, appraisal, development, dan dismissing staff. Staff development dimulai dari induksi staf dan dilanjutkan dengan berbagai metode dan teknik pengembangan staf. 
Proses manajemen sumber daya manusia menurut Lunenberg dan Ornstein (2012: 448) terdiri dari perencanaan sumber daya manusia, rekrutasi, seleksi, pengembangan keprofesian, penilaian kinerja, dan kompensasi. Pengembangan keprofesian adalah kegiatan meningkatan pengetahuan dan keterampilan yang dibutuhkan untuk mengisi posisi saat ini dan masa depan. Tiga langkah dasar dalam pengembangan keprofesian adalah pengukuran kebutuhan pengembangan profesi, pelatihan, dan evaluasi (Lunenberg dan Ornstein, 2012: 463).

Beberapa hasil penelitian tentang efektivitas implementasi PKB tidak konsisten antara yang satu dengan yang lain. Hasil penelitian Al Rasyid (2015) menunjukkan bahwa kelompok kerja guru efektif sebagai wadah PKB. Simpulan tersebut berbeda dengan hasil penelitian Murni dan Sumardjoko (2015) yang menunjukkan bahwa implementasi PKB belum berjalan secara maksimal. Hal ini karena terjadi beberapa kendala seperti pelaksanaan yang bersamaan dengan jam efektif sekolah. Penelitian serupa dihasilkanoleh Sujianto, Mukhadis, dan Isnandar (2012) bahwa PKB belum berjalan efektif yang dibuktikan bahwa sebagian besar guru hanya kadang-kadang melakukan investasi diri terkait tiga unsur PKB. Kendala-kendala dalam implementasi PKB ditunjukkan oleh Wiranti (2015) bahwa ada yang berasal dari diri guru seperti kurangnya waktu dan kemampuan, dan hambatan dari lembaga seperti kurangnya sarana dan prasarana pendukung.

Terkait dengan kondisi di atas, maka penelitian ini bertujuan untuk mengetahui: (a) bagaimanakah langkah-langkah pengembangan keprofesian berkelanjutan guru, (b) pendekatan dan metode pengembangan keprofesian berkelanjutan guru guru apa sajakah yang digunakan, (c) apa sajakah model-model pengembangan keprofesian berkelanjutan guru, (d) bagaimanakah pembiayaan pengembangan keprofesian berkelanjutan guru, dan (e) apa sajakah kendala-kendala implementasi pengembangan keprofesian berkelanjutan guru.

\section{METODE PENELITIAN}

Pendekatan penelitian yang digunakan adalah kualitatif sedangkan jenisnya adalah fenomenologis. Penelitian dilakukan di Kabupaten Demak tahun 2019.

Teknik pengumpulan data dengan wawancara, obsertasi, dan dokumentasi. Wawancara dilakukan terhadap guru, kepala sekolah, serta pengurus KKG dan MGMP yang respondennya dipilih secara acak sederhana sebanyak 25 orang. Observasi dilakukan terhadap 3 objek atau kegiatan. Penelusunan dokumen dilakukan terhadap 11 dokumen termasuk Peraturan Bupati dan Rensta Dinas Pendidikan dan Kebudayaan.

Langkah-langkah penelitianmengikuti model Miles dan Huberman dengan langkah detail sebagai berikut: a) mengumpulkan data melalui angket, wawancara, dan dokumentasi; b) temuan data dituliskan ke dalam memo sehingga peneliti bisa menemukan gagasan baru dan perspektif baru; c) selanjutnya temuan tersebut dikatagorisasikan untuk menemukan hubungan antar masalah; dan d) menarik simpulan dari temuan-temuan penelitian. Analisis data menggunakan software penelitian kualitatif NVivo 11 Plus.

\section{HASIL PENELITIAN DAN PEMBAHASAN}

Hasil Penelitian

\section{Langkah-langkahpengembangan} keprofesian berkelanjutan guru. Berdasarkan sumber data dari informasi wawancara, observasi, dan dokumentasi langkah-langkah pengembangan keprofesian berkelanjutan telah mengikuti teori yang telah banyak berkembang yaitu diawali dengan pengukuran kebutuhan guru yang perlu dikembangkan, kemudian pelaksanaan pengembangan keprofesian guru, dan evaluasi. 
Langkah-langkah implementasi PKB tersebut disederhanakan dari teori-teori yang berkembang oleh Davis dalam Gaol (2014: 216) menjadi pengukuran kebutuhan, pelaksanaan, dan diakhiri dengan tindak lanjut. Hal ini juga sesuai dengan yang dikembangkan oleh Lunenberg dan Ornstein(2012: 463).

Setelah dilakukan penelusuran lebih mendalam tentang langkah-langkah implementasi PKB tersebut, ternyata hasilnya tidak imbang antara responden yang memberikan respon dan sumber data yang menyatakan ada pengukuran kebutuan, pelaksanaan, dan evaluasi atas pelaksanaan PKB. Informanyang menyatakan bahwa ada kegiatan pengukuran dan evaluasi hanya diperoleh dari wawancara. Berdasarkan hasil observasi dan penelusuran dokumen tidak ditemukan adanya kegiatan need assessment dan evaluasi.

Apabila hasil wawancara, observasi, dan penelusuran dokumen yang menyatakan adanya langkah di setiap tahapan (pengukuran kebutuhan, pelaksanaan, dan evaluasi) maka hasilnya akan menunjukkan keseimbangan diantara ketiganya.Hanya dari sumber wawancara saja yang menunjukkan adanya ketiga langkah yang lengkap. Sementara itu dari observasi dan penelusuran dokumen tidak ditemukan bukti pengukurun kebutuhan dan evaluasi.

Bukti dari tidak adanya pengukuran kebutuhan pelatihan yang diperlukan guru dapat dilihat dari penelusuran dokumen yang hasilnya menunjukkan sebagai berikut.

"...tidak ditemukan adanya formulir evaluasi diri yang telah diisi oleh para guru, tidak ada need assessment kepada para guru yang akan mengambil PKB”. .....tidak ada dokumen formulir rencana PKB tingkat sekolah yang telah diisi oleh para guru..... tidak ditemukan formulir tingkat gugus yang telah diisi oleh setiap sekolah..." (D-3).

Berdasarkan berbagai sumber juga dapat diketahui bahwa terdapat 8 (delapan) materi yang dibahas dalam pengembangan keprofesian berkelanjutan guru yaitu: pelaksaan kurikulum 2013; penyusunan perangkat pembelajaran seperti silabus dan RPP (Rencana Pelaksanaan Pembelajaran); penilaian; media pembelajaran inovatif, karya tulis ilmiah seperti menulis di media massa, jurnal, maupun buku; penelitian tindakan kelas (PTK), penyusunan soal tinggkat tinggi (High Order Thinking Skills-HOTS), dan metodologi pembelajaran (tabel 1).

Dari hasil wawancara juga terungkap bahwa kebanyakan pelatihan yang diberikan sudah sesuai dengan kebutuhan guru, padalah dari awal tidak ada kegitan pengukuran kebutuhan pelatihan untuk guru.

Sebagian besar informan hasil wawancara menyatakan bahwa telah dilakukan evaluasi terhadap pelaksanaan PKB. Jawabannya bersifat normatif yaitu terkait pentingnya dilakukan evaluasi PKB. Terdapat satu sumber dokumen yang menyebutkan bahwa implementasi telah dilanjutkan dengan evaluasi (D-1). Walaupun simpulannya negatif yaitu:

“.....belum semua guru di gugus Kumbokarno melakukan tindak lanjut dari kegiatan PKB”.Artinya, gugus ini telah melakukan salah satu tahapan dalam siklus PKB yaitu melakukan evaluasi sesuai dengan tahap yang semestinya”. 
Tabel 1.Langkah-Langkah PKB menurut Sumber Informasi

\begin{tabular}{lccc}
\hline \multicolumn{1}{c}{ Langkah-Langkah } & Wawancara & Observasi & Dokumentasi \\
\hline 1. Pengukuran kebutuhan (need asseessment) & Ada & Tidak Ada & Tidak Ada \\
\hline 2. Pelaksanaan dan muatan materi & Ada & Ada & Ada \\
\hline 2.1. pelaksaan kurikulum 2013 & Ada & Tidak Ada & Ada \\
\hline 2.2. penyusunan pengakat pembelajaran & Ada & Tidak Ada & Ada \\
\hline 2.3. penilaian & Ada & Tidak Ada & Ada \\
\hline 2.4. media pembelajaran inovatif & Ada & Tidak Ada & Ada \\
\hline 2.5. karya tulis ilmiah & Ada & Tidak Ada & Ada \\
\hline 2.6. penelitian tindakan kelas (PTK) & Ada & Ada & Tidak Ada \\
\hline 2.7. penyusunan soal tinggkat tinggi (HOTS) & Ada & Tidak Ada & Tidak Ada \\
\hline 2.8. metodologi pembelajaran & Ada & Ada & Tidak Ada \\
\hline 3. Evaluasi & Ada & Tidak Ada & Tidak Ada \\
\hline
\end{tabular}

Sumber: data penelitian

\section{Metode \&teknik pengembangan} keprofesian berkelanjutan guru. Metode atau teknik yang diterapkan dalam PKB di Kabupaten Demak sudah banyak yang menggunakan saran-saran dari para ahli manajemen SDM bidang kependidikan. Diantaranya adalah penugasan seperti kuliah, menirukan peran sesuai karakter tertentu, pemodelan perilaku dengan menggunakan video, diskusi untuk memecahkan kasus tertentu, simulasi, on the job learning atau on the job training, dan mengikuti pendidikan dan pelatihan.

Metode dan teknik yang dikembangkan banyak mengadopsi teori yang dikembangkan oleh Dessler dalam Gaol (2014: 2017) yang mencakup lecture (kuliah mimbar), vestibule training, role playing, behavior modeling, case study, simulation, self study, dan program learning.

Dari berbagai metode tersebut yang paling banyak digunakan adalah pendidikan dan pelatihan (Diklat), kuliah, simulasi, diskusi, dan pemodelan perilaku. Sementara itu metode yang paling jarang digunakan adalah bermain peran dan on the job learning atau on the job training dengan cara magang di kelas lain atau di sekolah lain yang lebih baik.

Tabel 2.Metode dan Teknik yang digunakan dalam PKB Guru

\begin{tabular}{lcc}
\hline Jenis Metode dan Teknik & Frekuensi & Sumber Informasi \\
\hline 1. Kuliah & Tinggi & Wawancacara dan Dokumentasi \\
\hline 2. Diklat & Tinggi & Wawancara dan Dokumentasi \\
\hline 3. Simulasi & Tinggi & Wawancara dan Observasi \\
\hline 4. Diskusi & Tinggi & Wawancara dan Observasi \\
\hline 5. Pemodelan perilaku & Tinggi & Wawancara \\
\hline 6. Bermain peran & Rendah & Wawancara \\
\hline 7. OJT/OJL & Rendah & Wawancara \\
\hline
\end{tabular}

Sumber: data penelitian

Model pengembangan keprofesian berkelanjutan guru. Model-model pengembangan keprofesian berkelanjutan guru yang diterapkan pun sudah mengacu pada teori yang banyak dikemukakan oleh para ahli.

Yang terungkap dalam penelitian ini adalah para guru ikut dalam kelompok belajar 
profesional yaitu di KKG dan MGMP, para guru juga telah mendapatkan pendampingan dari para guru senior, para guru telah melakukan penelitian kolaboratif dengan guru senior atau dengan kepala sekolah, dan para guru telah mengikuti kegiatan seminar atau lokakarya, serta peer coaching.

Model PKB yang banyak diikuti oleh para guru adalah KKG dan MGMP. Tetapi berdasarkan pengakuan responden kegiatan tersebut tidak dilakukan secara teratur. Seperti pernyataan di bawah ini.

“....Guru ikut dalam kelompok belajar profesional, namanya KKG Rebon yaitu KKG yang dilaksanakan pada hari rabu yang disebut Rebon, namun tidak rutin dilaksanakan" (W.GSD.1).

Ada juga yang menyatakan bahwa kegiatan KKG dilaksanakan setiap hari sabtu sehingga dinamakan Septon. Pelasanaannya pun diakui belum rutin karena hanya dilakukan ketika ada kebutuhan mendesak. Pernyataan senada diberikan oleh W.GSMP.1 yaitu:

“....Saya mengikuti kelompok belajar profesional yaitu MGMP, kegiatannya membuat soal UAS (Ujian Akhir Sekolah) dan pendalaman materi kurikulum 2013. Jika sudah mendekati UAS (tidak rutin). Biasanya 6 bulan 1 kali”.

Demikian pula pernyataan W.GSMP-2 dengan pernyataannya:

" kegiatan yang saya ikuti untuk mengembangkan profesi adalah melalui MGMP. Kegiatannya yaitu menyusun soal Penilaian Akhir Semester (PAS) atau Penilaian Akhir Tahun (PAT) dan Ujian Sekolah Berstandar Nasional (USBN). Frekuensi pertemuan di MGMP belum intens, karena dilakukan hanya jika ada pembuatan soal PAS/PAT dan USBN".

Hal ini perlu menjadi perhatian Dinas Pendidikan dan Kebudayaan untuk menjadikan KKG dan MGMP sebagai wadah pengembangan keprofesian berkelanjutan bagi para guru.

Pembiayaan pengembangan keprofesian berkelanjutan guru. Peneliti memerinci sumber pembiayaan PKB dalam penelitian ini dari pribadi guru, iuran sekolah yang bersumber dari Bantuan Operasional Sekolah (BOS) dan sumber lain yang diterima sekolah, pemerintah dan pemerintah daerah, serta masyarakat.

Menurut pengakuan responden, sumber pembiayaan paling banyak bersumber dari pribadi guru. Sementara itu sumber dari pemerintah atau pemerintah daerah serta iuran sekolah masih kecil. Besarnnya pembiayaan PKB guru bervariasi antara Rp. 150.000 hingga Rp. 2 juta per tahun.

Berikut ini pengakuan dari para responden. Sumber dana PKB dari pribadi guru, Rp. 150.000-300.000 per tahun (W.GSMP-1). Sementara itu informasi dari sumber lain menyatakan bahwa sumber dana PKB dari guru bisa mencapai Rp. 2 juta rupiah dalam satu tahun (W.GSMP-6). Namun kebanyakan menyatakan bahwa sumber dana dari pribadi guru berada pada kisaran Rp. 300.000.

Secara jelas dinyatakan oleh sumber informan lain yang menyatakan, "saya telah mempersiapkan dana $4 \%$ dari tunjangan profesi guru saya, sesuai anjuran Bapak Bupati Demak untuk keperluan PKB” (W.GSD-7).

Berdasarkan sumber dokumen D-3 berupa Peraturan Bupati No. 53 tahun 2005 yang menyatakan bahwa:

"Bagi guru penerima tunjangan profesi pendidik wajib secara mandiri mendanai kegiatan pengembangan keprofesian berkelanjutan untuk dirinya sekurang-kurangnya $4 \% \quad$ (empat 
perseratus) dari tunjangan profesi

pendidik yang diterima".

Berdasarkan hasil wawancara, observasi, dan penelusuran dokumen tampak jelas bahwa tidak ada sumber pembiayaan PKB dari masyarakat. Hal ini menjadi temuan yang menarik untuk dibahas lebih lanjut, karena undang-undang sudah menjamin partisipasi masyarakat dalam pembiayaan pendidikan.Padahal di negara-negara maju seperti Australia sekalipun, masyarakat sudah berperan aktif dalam PKB (Henderson, 2007). Di sinilah perlunya pemerintah daerah dan pemerintah untuk membuat kebijakan untuk menggerakkan kepedulian masyarakat, misalnya melalui corporate social responsibility (CSR).

Sementara itu sumber resmi dari dokumen berupa Peraturan Bupati Tahun 2017, 2018, dan 2019 menunjukkan bahwa Pemerintah Daerah Kabupaten Demak telah memberikan bantuan pendidikan magister untuk Pegawai Negeri Sipil (PNS) yang akan mengembangkan diri. Dokumen tersebut menyebutkan:

“....Maksud bantuan biaya pendidikan adalah untuk membantu meringankan beban PNS yang akan melanjutkan pendidikan formal ke jenjang Strata-2 (magister) serta mendorong upaya peningkatan kompetensi PNS melalui pendidikan formal pada jenjang Strata-2, magister (D-2)"

Berdasarkan hasil wawancara, implementasi PKB dari Peraturan Bupati ini bagi PNS mendapatkan kesempatan melanjutkan pendidikan program magister dengan bantuan sebesar Rp. 15 juta selama empat (4) semester. Selama lima tahun masa kepemimpinan Bupati M. Nasir telah diprogramkan sebanyak 500 PNS akan mendapatkan bantuan pendidikan S2.
Kendala-Kendala implementasi pengembangan keprofesian berkelanjutan guru. Selama mengimplementasikan PKB terdapat beberapa kendala baik dari sisi guru, pengurus KKG dan MGMP, sekolah, pemerintah daerah, dan kendala dari sisi pembiayaan. Dari semua kendala tersebut kemudian disarikan apa yang menjadi kendala utama.

Kendala yang paling banyak adalah dari diri guru sendiri atau kendala internal, kendala dari sisi pemerintah daerah, dan hambatan dari lembaga seperti kurangnya sarana dan prasarana pendukung.

Berdasarkan pengakuan responden, kendala utama implementasi PKB adalah kurangnya nara sumber dan padatnya kegiatan guru di sekolah (W.GSD-1, W.GSD-3, W.GSMP-3, W.GSMP-6, W.GSMP-8, W.GSMP-9). Kendala utama lainnya adalah tidak adanya program dari pemerintah (W.GSD-2, W.GSMP-1, ). Kurangnya dana juga menjadi kendala utama (W.GSD-3). Setelah mengikuti pelatihan, ternyata tidak ada dukungan dari teman sejawat untuk mengimplementasikan hasil PKB (W.GSMP$5)$.

Ada satu hal yang menarik yang dinyatakan guru bahwa yang menjadi kendala utama PKB adalah tidak adannya tuntutan berubah setelah selesai pelatihan (W.GSMP-8). Kendala lain dari pendapat pengurus KKG yaitu tidak adanya pendampingan atau mentoring dari pengawas ke sekolah (W.KKG$1)$.

Kendala lain dari sisi guru adalah rendahnya kemampuan teknologi informasi pada guru terutama yang sudah senior (W.GSD-1). Informan lain mengaku bahwa setelah pelatihan tidak bersedia menularkan kepada guru lain (W.GSMP-10). Kurangnya minat atau motivasi guru untuk mengembangkan diri adalah kendala lain dari sisi guru, terutama guru yang sudah berusia tua (W.GSMP-2 dan W.GSM-5), dengan kata lain 
guru tidak mau berubah dari zona nyaman (W.GSMP-2). Keterbatasan fasilitas sekolah adalah menjadi kendala lain guru untuk mengembangkan diri (W.GSMP-3). Bahkan ada guru yang ikut seminar atau diklat hanya untuk mengejar sertifikat (W.GSMP-8).

Kendala dari sisi pemerintah daerah adalah tidak adanya alokasi dana (W.GSD-2, W.GSMP-1, W.GSMP-2, W.GSMP-9). Ternyata ada yang menyatakan bahwa jika ada pelatihan yang diberikan oleh Pemerintah Daerah, pelatihan yang diberikan tidak merata ke guru lain (W.GSMP-5). Selain itu Pemerintah Daerah jarang memprogramkan pelatihan kepada guru (W.GSMP-8). Pelatihan yang diberikan oleh Pemda biasanya waktunya terlalu singkat sehingga tidak maksimal (W.GSMP-6). Tidak adanya penugasan dari Dinas Pendidikan ke Pengawas untuk mendampingi guru di sekolah dianggap sebagai kendala dari sisi Pemerintah Daerah (W.KKG1 dan W.KKG-2).

Implementasi PKB yang telah dilakukan secara intensif di Kabupaten Demak selama 5 tahun terakhir telah berdampak positif terhadap peningkatan mutu pendidikan. Hal ini dapat dilihat dari data Neraca Pendidikan Daerah 2015-2018 dari tiga indikator terkait kualitas guru yaitu kualifikasi akademik guru SD meningkat dari $93,1 \%$ di tahun 2015 menjadi 94,4 di tahun 2018 dan kualifikasi akademik guru SMP meningkat dari $89 \%$ di tahun 2015 menjadi 94,8 di tahun 2018. Demikian pula rerata nilai UKG guru SD meningkat dari 60 di tahun 2015 menjadi 60,46 di tahun 2017 dan retata nilai UKG guru SMP meningkat dari 64 di tahun 2015 menjadi 64,4 di tahun 2017. Di sisi lain rerata lama sekolah di Kabupaten Demak meningkat dari 7,40 di tahun 2015 mejadi 7,47 di tahun 2018 (www.kembidbud.go.id).

\section{PEMBAHASAN HASIL PENELITIAN}

Langkah-langkah pengembangan keprofesian berkelanjutan guru. Hasil penelitian di atas menunjukkan bahwa PKB di Kabupaten Demak belum ada langkah pertama yaitu pengukuran kebutuhan secara baik dan belum ada evaluasi terhadap pelaksanaan PKB. Dalam PKB terdapat tiga langkah penting yaitu pengukuran kebutuhan guru, implementasi, dan evaluasi sebagaimana dikemukakan oleh Davis dalam Gaol (2014: 216) dan Lunenberg \&Ornstein(2012: 463). Jika langkah pertama dan ketiga tidak dilakukan maka implementasinya tidak akan efektif dan efisien.

Hal ini dapat diartikan bahwa sebenarnya implementasi PKB belum dilaksanakan secara efektif sesuai dengan langkah-langkah yang dikemukakan oleh para ahli. Ada pelaksanaan, tetapi tidak dimulai dari pengukuran kebutuhan guru. Parahnya lagi, tidak ada evaluasi setelah pelaksanaan sebagai alat untuk mengetahui apakah yang dilaksanakan sudah sesuai dengan yang direncanakan untuk memenuhi kebutuhan guru, ataukah sudah berhasil atau belum.

Studi kasus yang dilakukan Sianturi (2013) menemukan kebutuhan pengembangan keprofesian guru berdasarkan karakteristik mereka. Artinya need assessment dalam PKB menjadi langkah yang sangat penting agar tepat sasaran.

Materi yang banyak dibahas dalam PKB di Kabupaten Demak adalah karya tulis ilmiah, penelitian tindakan kelas, kurikulum 2013, dan penyusunan perangkat pembelajaran. Sementara itu materi yang kurang banyak dibahas dalam PKB adalah penilaian, penyusunan soal HOTS, pembuatan media pembelajaran inovatif, dan metodologi pembelajaran.

Hal ini sesuai dengan hasil penelitian Sianturi (2013: 16-24) yang menyatakan bahwa PTK dan metodologi pembelajaran adalah materi yang diperlukan untuk dilatihkan dalam PKB. 
Metode \&teknik pengembangan keprofesian berkelanjutan guru. Metode dan teknik PKB yang paling banyak digunakan adalah Diklat, kuliah, simulasi, diskusi, dan pemodelan perilaku. Sementara itu metode yang paling jarang digunakan adalah bermain peran dan on the job learning atau on the job training.

Metode dan teknik PKB yang banyak digunakan di Kabupaten Demak tampaknya adalah yang mudah dilakukan dan sudah biasa dilakukan oleh para guru. Sementara itu on the job training/learining jarang digunakan karena proses pelaksanaannya lebih rumit.

Padahal menurut Noe. et al. (2003) on the job training ini sebagai upaya memfasilitasi peningkatan pengetahuan staf terkait pekerjaan, keterampilan, dan perilaku. Maka ini merupatan teknik yang tepat untuk meningkatkan kompetensi profesional, pedagodik, kepribadian, dan sosial guru. On the jon training merupakan teknik bekerja sambil belajar yang praktis untuk diterapkan.

Hasil penelitian yang dilakukan oleh Nainggolan, Sunuharyo, dan Aini (2018: 112119) menunjukkan bahwa on the job trainingmempunyai pengaruh yang signifikan terhadap kinerja karyawan. Jika hal ini diterapkan pada guru-guru melalui PKB maka besar kemungkinan kinerja guru dalam mengajar akan lebih baik. Sehingga mutu pendidikan di Kabupaten Demak akan demkain baik.

Model pengembangan keprofesian berkelanjutan guru. Model-model PKB yang diterapkan di Kabupaten Demak sesuai yang dikenalkan oleh Diaz-Maggioli (2004) yaitu dengan cara membentuk kelompok belajar profesional, mentoring, penelitian tindakan kolaboratif, peer-coaching, menulis, ikut dalam tim pengembangan keprofesian kritis, dan menghadiri konferensi serta seminar.

Model yang paling sedikit diterapkan adalahpeer coahing atau magang. Karena untuk melakukan magang di kelas lain atau di sekolah lain, seorang guru harus meninggalkan tugas mengajar di kelas. Sedangkan di sekolah tidak ada guru pengganti. Hal ini berbeda seperti yang terjadi di Amerika Serikat (Gallo-Fox dan Scantlebury, 2016) dalam PKB salah satunya dilakukan dengan kolaborasi antara guru dengan menjadi coteacher bagi guru lain.

Model yang paling banyak digunakan adalah kelompok belajar profesional dalam bentuk KKG dan MGMP.Namun kebanyakan guru yang menjadi responden penelitian mengatakan bahwa kegiatan KKG atau MGMP tidak dilaksanakan secara rutin karena hanya dilaksanakan jika ada kebutuhan yang mendesak.

Berdasarkan hasil penelitian ini dirasa penting agar Dinas Pendidikan dan Kebudayaan membuat kebijakan untuk menggunakan KKG dan MGMP sebagai wadah pengembangan keprofesian guru secara berkelanjutan. Lebih baik lagi juga Dinas Pendidikan dan Kebudayaan memberikan dukungan dana dan sarana prasarana di KKG dan MGMP.

Pembiayaan pengembangan keprofesian berkelanjutan guru. UndangUndang No. 20 Tahun 2003 tentang Sistem Pendidikan Nasional menyebutkan bahwa pembiayaan pendidikan bisa bersumber dari Pemerintah, Pemerintah Daerah, dan Masyarakat. Namun berdasarkan jawaban responden wawancara, sumber dana kebanyakan bersumber dari pribadi masingmasing guru.

Hal ini berbeda dengan temuan penelitian Sujianto, Mukhadis, dan Isnandar (2012) yang menyatakan bahwa PKB belum berjalan efektif yang dibuktikan bahwa sebagian besar guru hanya kadang-kadang melakukan investasi diri untuk PKB.

Berdasarkan hasil penelitian ini justru sumber pendanaan PKB sebagian besar berasal dari guru itu sendiri. Tampaknya para guru di Kabupaten Demak sudah menyadari 
akan keterbatasan pemerintah dan pemerintah daerah yang dinyatakan Damin (2011: 8) bahwa di Indonesia hanya 5\% guru yang memiliki peluang mengembangkan keprofesiannya jika mengandalkan pemerintah atau pemerintah daerah.

Kesadaran para guru di Kabupaten Demak sudah tumbuh untuk mengembangkan profesionalismenya tidak terlepas dari Peraturan Bupati No. 53 tahun 2005 tentang Pembinaan dan PengembanganKeprofesian Berkelanjutan Bagi Guru Di Lingkungan Pemerintah Kabupaten Demak. Namun belum ada mekanisme yang jelas bagaimana proses pengumpulan dana $4 \%$ dari setiap guru, siapa yang bertanggungjawab untuk mengelola, dan bagaimana mekanisme penggunaannya. Sehingga Dinas Pendidikan dan Kebudayaan perlu membuat Prosedur Operasional Standar (POS) agar implementasi Peraturan Bupati ini dapat dilaksanakan secara efektif.

\section{Kendala-Kendala implementasi pengembangan keprofesian berkelanjutan} guru. Kendala yang paling banyak adalah dari diri guru sendiri atau kendala internal. Hal ini sesuai dengan hasil penelitian Wiranti (2015) bahwa kendala PKB ada yang berasal dari diri guru seperti kurangnya waktu dan kemauan.

Juga ada hambatan dari lembaga seperti kurangnya sarana dan prasarana pendukung. Hal ini juga sejalan dengan penelitian Maksum (2015) yang menyatakan bahwa kendala utama PKB adalah dari guru itu sendiri walaupun kepala sekolah sudah memberikan dukungan.

Kendala lain implementasi PKB adalah kurangnya nara sumber dan padatnya kegiatan guru di sekolah. Hal ini seduai dengan hasil penelitian Murni dan Sumardjoko (2015) bahwa karena PKB dilaksanakan pada jam pelajaran efektik maka waktunya berbenturan, sehingga guru mengalami kesulitan.

\section{SIMPULAN DAN SARAN}

\section{Simpulan}

Dari tiga langkah $\mathrm{PKB}$, pengukuran kebutuhan dan evaluasi belum dilakukan. Implementasi PKB sudah dilaksanakan walau tanpa ada perencanaan dan evaluasi kegaitan. Dari langkah PKB ini dapat disimpulkan bahwa impelementasi $\mathrm{PKB}$ belum berjalan secara efektif.

Materi yang paling banyak diberikan dalam PKB adalah karya tulis ilmiah, penelitian tindakan kelas, implementasi kurikulum 2013, dan penyusunan perangkat pembelajaran. Materi yang kurang dibahas dalam PKB adalah penilaan, penyusunan soal tingkat tinggi, pembuatan media pembelajaran inovatif, dan metodologi pembelajaran.

Metode dan teknik PKB yang paling banyak digunakan adalah diklat, kuliah, simulasi, diskusi, dan pemodelan perilaku. Sementara itu yang paling jarang digunakan adalah bermain peran dan on the job training.

Model PKB yang paling banyak digunakan adalah kelompok belajar profesional dalam bentuk KKG dan MGMP.Sementara itumodel peer coahing atau magang adalah yang paling sedikit digunakan. Hal ini dikarenakan waktu yang diperlukan lebih lama dan menggunakan sumber daya yang lebih banyak.

Pembiayaan terbesar dalam PKB adalah dari pribadi guru yang rata-rata menyisihkan Rp. 300.000, hal ini mengikuti anjuran Peraturan Bupati bahwa setiap guru yang sudah sertifikasi mengalokasikan $4 \%$ dari tunjangan profesinya untuk mengembangkan keprofesiannya. Pemerintah Daerah Kabupaten Demak telah mengalokasikan bantuan pendidikan untuk PNS yang akan melanjutkan pendidikan S2 sebesar Rp. 15 juta selama 4 semester.

Kendala utama implementasi PKB adalah kurangnya nara sumber, padatnya kegiatan guru di sekolah, tidak adanya program dari pemerintah daerah, kurangnya dana, tidak 
adanya dukungan dari teman sejawat, tidak adannya tuntutan berubah setelah selesai pelatihan, dan tidak adanya pendampingan dari pengawas ke sekolah.

Kendala dari sisi guru adalah rendahnya kemampuan teknologi informasi pada guru, setelah pelatihan guru tidak bersedia menularkan kepada guru lain, kurangnya minat atau motivasi guru untuk mengembangkan diri, dan keterbatasan fasilitas sekolah, serta guru hanya mengejar sertifikat.

Kendala dari sisi pemerintah daerah adalah pelatihan yang diberikan tidak merata, jarang memprogramkan pelatihan, waktu pelatihan terlalu singkat, tidak adanya penugasan kepada pengawas sekolah untuk mendampingi guru.

\section{Saran}

Berdasarkan simpulan di atas, agar PKB dapat meningkatkan mutu pendidikan lebih baik lagi di Kabupaten Demak maka disarankan beberapa hal sebagai berikut: (1) langkahlangkah PKB perlu diperbaiki mulai dari pengukuran kebutuhan guru hingga evuasi, (2) metode, teknik, dan model yang masih jarang digunakan hendaknya dicoba untuk diterapkan, (3) perlu penggalian pembiayaan dari masyarakat, (4) meminimalisir kendalakendala utama yang muncul, dan (5) perlu adanya kebijakan yang lebih operasional di Dinas Pendidikan dan Kebudayaan.

\section{DAFTAR PUSTAKA}

Al Rasyid. 2015. Fungsi Kelompok Kerja Guru (KKG) bagi Pengembangan Keprofesian Guru Sekolah Dasar. Sekolah Dasar, Tahun 24 No. 2 November 2015: 143.

Chow, Alice. 2013. Professional Learning Communities In Three Subject Departments In Hong Kong Secondary Schools. International Journal of Arts \& Sciences, CD-ROM. ISSN: 19446934 : 6(4):233-245.
Danim, S. 2011. Pengembangan Profesi Guru Dari Pra-Jabatan, Induksi, ke Profesional Mandiri. Jakarta, Kendana Prenada Media Group.

Diaz-Maggioli, G. 2004. Teacher-Centered Professional Development. VirginiaUSA, Association for Supervision and Curriculum Development (ASCD).

Everard, K.B; Morris, G; and Wilson I. 2004. Effective School Management. $4^{\text {th }}$ Edition. California, Sage Publication Inc.

Gallo-Fox, Jennifer dan Scantlebury, Kathryn. 2016. Coteaching as professional development for cooperating teachers. Teaching and Teacher Education 60: 191-202.

http://dx.doi.org/10.1016/j.tate.2016.08 .007 .

Gaol, Jimmy L. 2014. A to Z Human Capital. Manajemen Sumber Daya Manusia: Konsep, Teori, dan Pengembangan dalam Konteks Organisasi Publik dan Bisnis. Jakarta, Gramedia Widiasarana Indonesia.

Henderson, Michael. 2007. Sustaining online teacherprofessional development through community design. CampusWide Information Systems Volume 24 Number 3, 2007, pp. 162-173.

Kementerian Pendidikan dan Kebudayaan. 2015-2018. Nerada Pendidikan Daerah Tahun 2015 Provinsi Jawa Tengah. www.kemdikbud.go.id.

Lunenburg, F.C and Ornstein, A.A. 2012. Education Administration: Concepts and Practices. Sixth Edition, International Edition, Wadsworth Cengage Learning.

Maksum. 2015. Pelaksanaan Pengembangan Keprofesian Berkelanjutan Guru Kelas SD Negeri 2 Tarakan. Jurnal Kebijakan 
dan Pengembangan Pendidikan Volume

3, Nomor 1, Januari 2015; 75-81 ISSN:

2337-7623; EISSN: 2337-7615.

Murni dan Sumardjoko, B. 2015. Analisis Pengembangan Keprofesian Berkelanjutan Guru SMK Muhammadiyah 3 dan 6 Gemolong Sragen. Tesis. Fakultas Pascasarjana Magister Manajemen Pendidikan.

Nainggolan, W.D.M; Sunuharyo, B.S; danAini, E.K.2018. Pengaruh On The Job Training Dan Off The Job Training Terhadap Kinerja Karyawan. Jurnal Administrasi Bisnis (JAB)|Vol. 60 No. 3 Juli 2018, 112-119.

Noe, Hollenbeck, Gerhart, Wright. 2003.Human Resource Management, International Edition, The McGraw-hill Companies, Inc. New York.

Peraturan Bupati Demak Nomor 23 Tahun 2017 tentang Bantuan Biaya Pendidikan Program Magister Bagi Pegawai Negeri Sipil Di Lingkungan Pemerintah Kabupaten Demak.

Peraturan Bupati Demak Nomor 27 Tahun 2018 tentang Perubahan Atas Peraturan Bupati Demak Nomor 23 Tahun 2017 Tentang Bantuan Biaya Pendidikan Program Magister Bagi Pegawai Negeri Sipil Di Lingkungan Pemerintah Kabupaten Demak.

Peraturan Bupati Demak Nomor 40 Tahun 2019 tentang Perubahan Kedua Atas Peraturan Bupati Demak Nomor 23 Tahun 2017 Tentang Bantuan Biaya Pendidikan Program Magister Bagi Pegawai Negeri Sipil Di Lingkungan Pemerintah Kabupaten Demak.

Peraturan Bupati Demak Nomor 53 Tahun 2015 tentang Pembinaan dan
PengembanganKeprofesian

Berkelanjutan Bagi Guru Di Lingkungan Pemerintah Kabupaten Demak.

Peraturan Periden Republik Indonesia Nomor 2 Tahun 2015 tentang Rencana Pembangunan Nasional Menengah Nasional 2015-2019.

Rencana Strategis Dinas Pendidikan Kabupaten Demak Tahun 2016-2021.

Sianturi, Canni Loren. 2013. Asesmen Kebutuhan Pengembangan

Profesionalisme Guru SMK. Jurnal Pendidikan Humaniora, Volume 1 Nomor 1, Maret 2013: 16-24.

Sujianto; Mukhadis, A; dan Isnandar. 2012. Pengembangan Profesionalitas

Berkelanjutan Guru Bersertifikat Pendidik di SMK Rumpun Teknologi. Teknologi Kejuruan, Volume 35 No. 1 Februari 2012: 1.

Undang-Undang Republik Indonesia Nomor 20 Tahun 2003 tentang Sistem Pendidikan Nasional.

Wiranti, N. 2015. Pengembangan Profesionalitas Guru Taman KanakKanak Bersertifikasi di Kecamatan Nanggulan Kulon Progo. Jurnal Pendidikan Guru Anak Usia Dini, Edisi 6 Tahun ke-4, 2015: 1.

Wuryandiri, Endang. 2014. Analisis Permasalahan dan Kebutuhan Pengembangan Keprofesian Berkelanjutan Guru SMK Bidang Keahlian Bisnis dan Manajemen Pascasertifikasi Di Kota Semarang. Jurnal Manajemen Pendidikan, Volume 9, Nomor 2, Juli 2014: 108-119. 